\title{
Primary small cell carcinoma of the thyroid: a case report
}

\author{
Carcinoma de pequenas células primário da tireoide: relato de caso
}

Maria Clara Martins Prado ${ }^{1,2 *}$, Isabella Rocha França Longo Staino ${ }^{1,2}$, Hannah Damasceno Barreto da Silva ${ }^{3}$, Alexandre Fonseca de Castro ${ }^{1,4}$, Lysio França ${ }^{3}$, Paula Ferreira Barros ${ }^{5}$.

\begin{abstract}
The diagnosis of cervical mass is a challenge due to the wide variety of benign and malignant etiologies. Extrapulmonary small cell carcinomas (EPSCC) are rare entities, and those tumours arising as a primary cervical, especially in the thyroid gland, are exceedingly rare. As others small cell neuroendocrine carcinomas, the disease has an aggressive behavior. This case report is about a 40-years-old female patient admitted to the Hospital Felício Rocho, with airway compression caused by a cervical mass originated in the thyroid gland. The data were extracted from the medical records and information provided by the attendants. We describe here the multidisciplinary approach used to treat the patient as well as her outcome. We also review the clinical and molecular aspects of this rare entity.
\end{abstract}

Keywords: Carcinoma; Neuroendocrine tumors; Thyroid gland; Molecular biology; Diagnosis; Differential.

\begin{abstract}
RESUMO
O diagnóstico de massa cervical é um desafio devido à ampla variedade de etiologias benignas e malignas. Os carcinomas de pequenas células extrapulmonares (CPCEP) são entidades raras e esses tumores que surgem como primários na região cervical são ainda mais raros, especialmente na glândula tireoide. Assim como outros carcinomas de pequenas células neuroendócrinos, a doença apresenta comportamento agressivo. Esse relato de caso é sobre uma paciente mulher de 40 anos, internada no Hospital Felício Rocho, com compressão das vias aéreas causada por uma massa cervical originada na glândula tireoide. Os dados foram extraídos dos prontuários e informações fornecidas pelos assistentes. Descrevemos aqui a abordagem multidisciplinar usada para tratar a paciente, bem como o seu resultado. Também revisamos os aspectos clínicos e moleculares dessa rara entidade.

Descritores: Carcinoma; Tumores neuroendócrinos; Glândula tireoide; Biologia Molecular; Diagnóstico; Diferencial.
\end{abstract}

\footnotetext{
1. Hospital Felicio Rocho, Clinical Oncology - Belo Horizonte - Minas Gerais - Brazil

2. Fundação Educacional Lucas Machado (FELUMA), Pós-Graduação Ciências Médicas de Minas Gerais (PGCM- MG) - Belo Horizonte - Minas Gerais - Brazil

3. Hospital Felicio Rocho, Head and Neck Surgery - Belo Horizonte - Minas Gerais - Brazil

4. ONCOMED - Center for treatment and prevention of neoplastic diseases, Clinical Oncology - Belo Horizonte - Minas Gerais - Brazil

5. Santa Casa de Misericordia, Pathology - Belo Horizonte - Minas Gerais - Brazil
}

Financial support: none to declare.

Conflicts of interest: The authors declare no conflict of interest relevant to this manuscript.

Correspondence author: Maria Clara Martins Prado. Hospital Felicio Rocho, Oncomed, Clinical Oncology.

Rua Doutor Veloso, 1187, apartamento 304, Centro, Montes Claros, Minas Gerais, Brasil, CEP 39400074.

E-mail: mclaraprado@hotmail.com

Received on: August 28, 2018 | Accepted on: June 13, 2019

DOI: $10.5935 / 2526-8732.20190013$ 


\section{INTRODUCTION}

The diagnosis and management of cervical masses are eventually a challenge for the oncologist and the head and neck surgeon. There are a variety of malignant and non-malignant entities that can present with a growing mass in the neck. When we look at malignant thyroid masses specifically, the carcinomas, including papillary, folicular, medular and anaplastic are the most frequent tumours. The extrapulmonary small cell neuroendocrine carcinoma (EPSCC) is a rare type of cancer that can virtually arise from any organ, being even more rare in the thyroid gland. Its postulated that just $2-5 \%$ of small cell neuroendocrine carcinomas arise at extrapulmonary sites, and being such a rare entity, data regarding its epidemiology is scarce. It is thought to arise from a multipotent stem cell with neuroendocrine features. The microscopic appearance resembles small cell carcinoma of the lung, so its important to differentiate a metastasis from a pulmonary tumor from an extrapulmonary primary. The clinical features also remember the small cell lung cancer behavior, with rapid growing tumours and frequent systemic dissemination, carrying a dismal prognosis. As well as others neuroendocrine carcinomas from other sites a multidisciplinary approach is essential, and efforts to better understand molecular mechanisms that trigger the disease are very important.

\section{CASE REPORT}

This case report is about a 40-years-old female patient admitted to the Hospital Felício Rocho, in Belo Horizonte, Minas Gerais, with airway compression caused by a rapid growing cervical mass that appeared few weeks before (Figure 1). A computed tomography showed a tumor with epicenter in the thyroid gland. At this time she was taken to an intensive care unit for ventilatory support. She was submitted to a fine needle aspiration procedure twice without a definitive diagnosis. A core biopsy was then performed. The microscopic study of the lesion suggested that it was an undifferentiated small cell tumour. Systemic staging with computer tomography of thorax and abdomen did not show distant metastases, or signs of pulmonary primary neoplastic lesion. While the immunohistochemical study was ongoing, chemotherapy with intravenous cyclophosphamide $500 \mathrm{mg}$ for three days and decompressive radiotherapy ( 3 x 200cGy) were instituted as a matter of urgency, as the mass was extensive and obstructive. There was a significant reduction in the cervical mass on the following days, allowing the patient to be extubated and discharged from the intensive care unit.

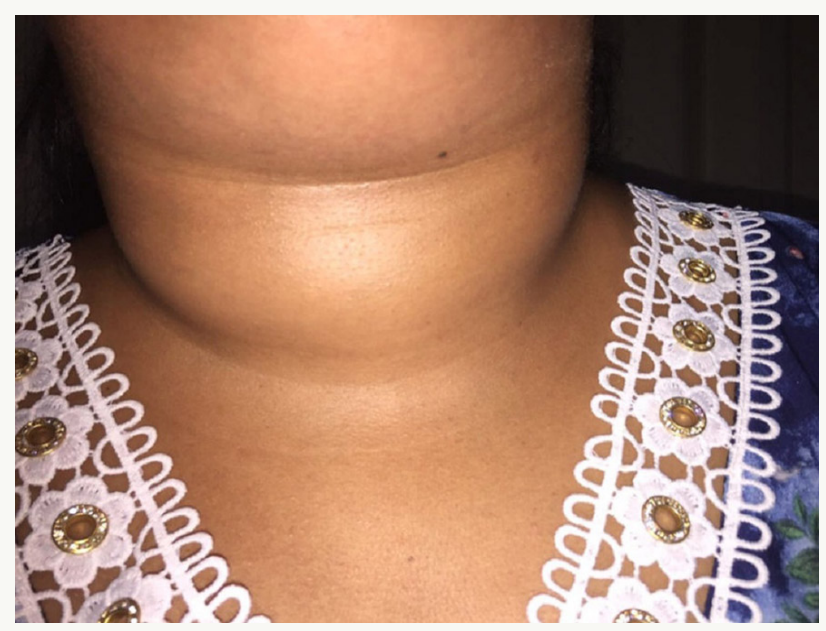

Figure 1. Fast and progressive growth mass in the cervical region.
The initial immunohistochemical panel ruled out the possibility of lymphoma, as markers of epithelial differentiation (cytokeratins/EMA) were positive and lymphoid markers were negative. Figura 2 Since there was immunohistochemical expression of FLI1 , the pathologist suggested a differential diagnosis between primitive neuroectodermal tumor and small cell neuroendocrine carcinoma. The positivity of this marker suggests the first hypothesis and a marking of synaptophysin that was seen is related to the last diagnosis. The search for chromosomal rearrangement of the EWS gene by fluorescence in-situ hybridization technique (FISH) was negative. Serum calcitonin was negative.

The attending physicians debated the case and opted for thyroidectomy. During the procedure, the surgeon noted a thyroid gland with macroscopic alterations such as darkened color, friable tissue and periglandular fibrosis, which prevented its complete dissection and identification of the inferior laryngeal nerve. Therefore, a "near total" lobectomy was performed on the left side, due to the possibility of bilateral nerve injury if surgery continued under these circumstances. After surgery, rigid videolaryngoscopy showed preserved mobility of the vocal folds bilaterally, suggesting that there was no nerve damage.

The histopathological report and immunohistochemistry of the postoperative specimen showed positivity of TTF-1, CD56 and synaptophysin, suggesting the diagnosis of small cell neuroendocrine carcinoma of the thyroid. TTF-1 is expressed in lung and thyroid carcinoma, and CD56 and synaptophysin positivity are suggestive of neuroendocrine differentiation. There were still palpable lymph nodes in the neck after surgery. "Ultrasonography evidenced numerical prominence of lymph nodes in bilateral cervical chains, some with increased dimensions, suspec ted for secondary neoplastic involvement (figure 3). A solid nodule was also identified in the right lobe of the thyroid measuring $0.9 \times$ " $0.6 \times 0.5 \mathrm{~cm}$. (figure 4). 


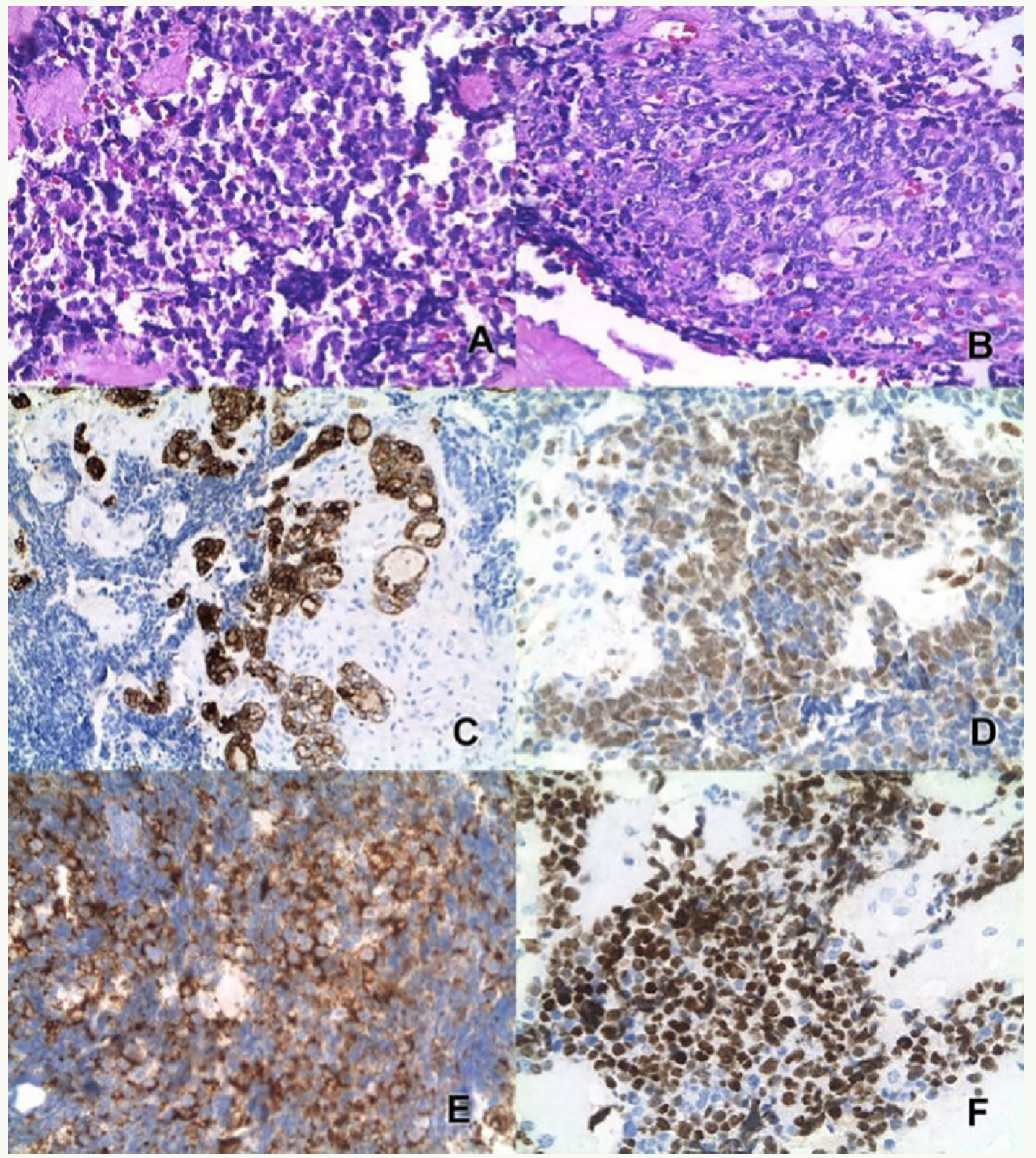

Figure 2. Neoplastic tissue stained in H\&E (A), areas of epithelial arrangement (B). In the reaction for cytokeratins, the small cells areas are negative, with expression in epithelial groups (C). Expression of FLI-1 (D), CD56 (E) and TTF-1 (F).

The patient underwent four cycles of chemotherapy with the EP protocol (Etoposide + Cisplatin), remaining with a small cervical lymph node clinically visible after the fourth cycle. She was then submitted to radiotherapy at this lymph node site (30 x $1.8 \mathrm{~Gy})$ and lymphatic cervical drainage (25 x $1.8 \mathrm{~Gy})$. After radiotherapy, the lymph nodes disappeared and were not visible or palpable. She was referred again to the head and neck surgeon to evaluate the possibility of resection of the remanescent thyroid. However, before the surgery was done, about one month later after finishing the neck radiotherapy, a strong lumbar back pain started. A nuclear magnetic resonance of the spine showed metastasis in lumbar vertebra with radicular compression in L5/S1. A surgical decompression was done, with rapid pain improvement. The pathological report was compatible with metastatic small cell neuroendocrine carcinoma. Restaging tomography of thorax and abdomen showed metastasis in many posterior lumbar vertebras and left external iliac lymphadenomegaly. The patient started with 

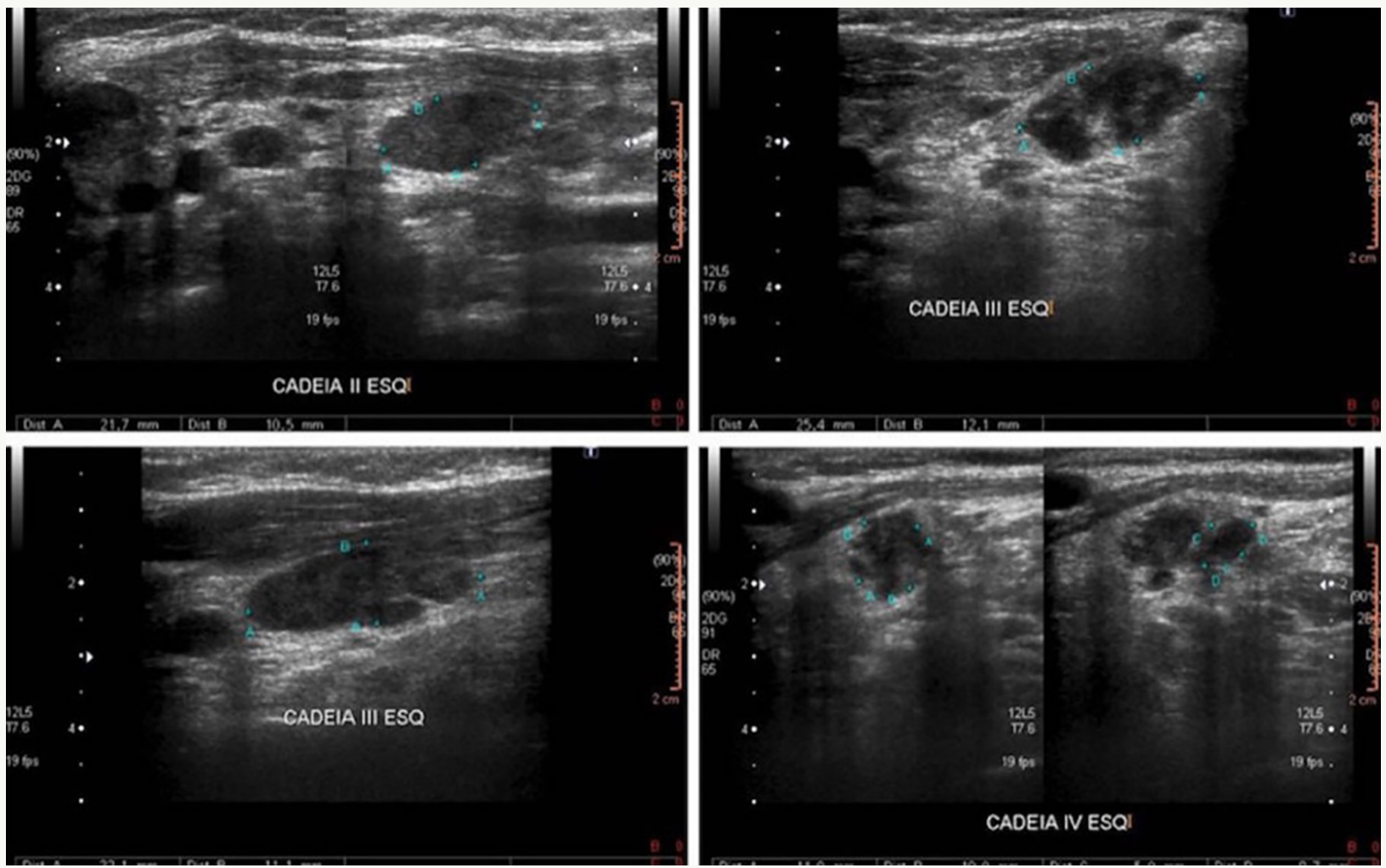

Figure 3. Bilaterally prominent cervical lymph nodes, more on the left. Some of them have globules, heterogeneous and/or irregular contours, with no obvious greasy threads, suspected for secondary neoplastic involvement

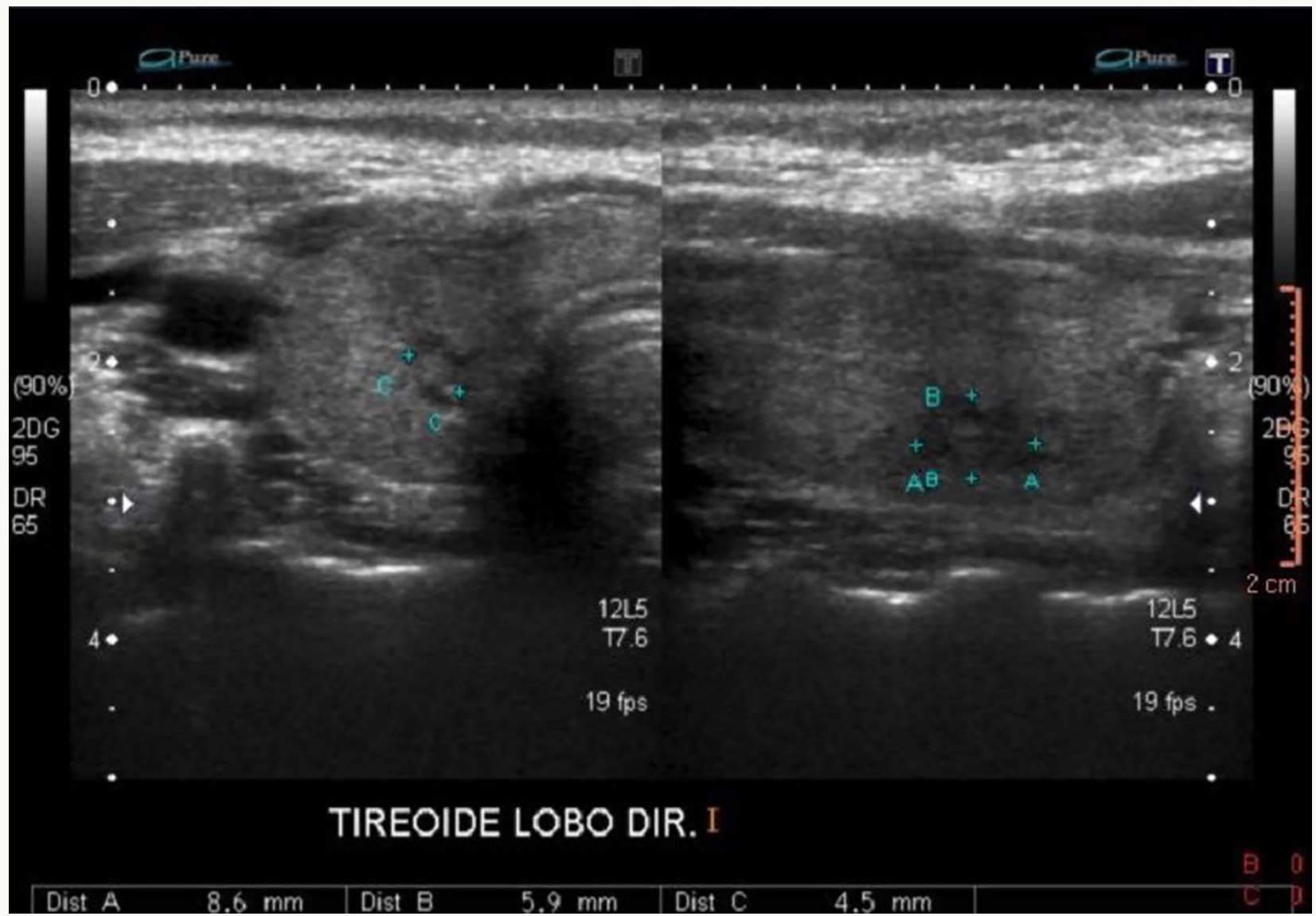

Figure 4. A predominantly isoechoic heterogeneous solid nodule with hypoechoic areas of permeation, imprecise limits and no apparent calcification in the lower third of the right lobe, measuring about $0.9 \times 0.6 \times 0.5 \mathrm{~cm}$. 
VCA chemotherapy (vincristine, cyclophosphamide, doxorubicin) every three weeks. About three weeks after the second cycle (before receiving the third), there was again worsening of the lumbar pain (L2) and a new magnetic resonance showed radicular compression in the second lumbar vertebra. The third cycle was postponed and the patient is on local palliative radiotherapy, which is still ongoing.

\section{DISCUSSION}

Small cell neuroendocrine carcinomas are a group of malignant tumours that can virtually arise from any organ, but lung primaries are the most frequent ones and primary lesions in the head and neck are very rare. Extrapulmonary small cell carcinoma (EPSCC) compromises only $2.5-4 \%$ of all small cell carcinomas, with an overall incidence of approximately 0.1 to $0.4 \%$ of all cancers. ${ }^{1}$ According to the National Comprehensive Cancer Network (NCCN), the most common extrapulmonary sites of origin, in order of decreasing frequency, are the cervix, oesophagus, head and neck. ${ }^{2}$ These tumours have been reported to arise from a wide variety of other sites including the prostate, $^{3}$ bladder, $^{4}$ colon, pancreas, rectum, stomach, gallbladder, ${ }^{5}$ kidney, ${ }^{6}$ breast, ${ }^{7}$ endometrium and ovary. ${ }^{8}$ In the head and neck region, the most common sites are the larynx, nose, and paranasal sinuses, and the major salivary glands. ${ }^{9,10,11}$

Primary small cell neuroendocrine carcinoma of the thyroid are extremely rare, and just a few cases have been described in literature. ${ }^{12,13,14,15,16}$ These tumours are different diseases from anaplastic variants of medullary thyroid carcinomas that have markers of C-cell derivation. ${ }^{12}$ It is an exceedingly rare neoplasm with expression of neuroendocrine markers but lacking calcitonin immunoreactivity and C-cell differentiation. Before the advent of immunohistochemistry many cases of low grade lymphoma, undifferentiated carcinomas (insular) and medullary small cell variants were described as small cell carcinomas of thyroid gland. ${ }^{12,17,18}$ In our reported case the initial differential diagnosis was between primitive neuroectodermal tumor (PNET) and small cell neuroendocrine carcinoma. These entities are rarely originated in the thyroid. The search for chromosomal rearrangement involving the EWS gene (by fluorescence in-situ hybridization technique - FISH) is a tool with good accuracy that significantly helps the diagnosis of Ewing's sarcoma. ${ }^{18}$ TTF-1 is expressed in lung and thyroid carcinoma, and CD56 and synaptophysin positivity are suggestive of neuroendocrine differentiation. The search for EWS rearrangement (FISH) was negative in our case. Also, serum caltinonin was normal, arguing against medullary carcinoma with small cell features.
In the same way as small cell lung carcinomas (SCLC) and extrapulmonary primaries share similar morphology, some molecular alterations appear to be also common in both entities. Overexpression of $\mathrm{p53}, \mathrm{Rb}$ inativation increased bcl-2 expression, telomerase activation, k-ras mutation and c-myc amplification were described, ${ }^{19,20}$ suggesting that maybe there is a common early precursor molecular triggering event. Despite this, EPSCC can show different cytogenetical characteristics, as loss of chromosome $3 p$ is common in SCLC but rare in the former. ${ }^{21}$ Cytogenetic abnormalities, such as microsatellite instability, loss of heterozygosity and chromosome deletion or loss have been reported in EPSCCS from gastrointestinal tract, gallbladder, cervix, urinary bladder and breast. ${ }^{20} \mathrm{~A}$ significant proportion of EPSCC (36\%) also show c-kit expression, and it could be a potential target for testing therapeutic agents. ${ }^{22}$

EPSCC is characterised by aggressive clinical behaviour and dismal outcome with currently available treatment strategies. ${ }^{1}$ The clinical behaviour of these tumours is generally aggressive because of frequent metastases and recurrences like their pulmonary counterparts. Although EPSCC has histological similarity with small cell lung cancer and also a poor prognosis, some authors point some different outcomes in some cases, as the clinical and biological behaviour can vary with the site of origin and the extent of the cancer. ${ }^{23}$ The disease arising in female genital tract and organ limited is associated with a better survival. ${ }^{24}$ When a diagnosis of EPSCC arising in the head and neck region is made, the patient should be evaluated first to determine whether the disease is a primary or metastatic cancer. Primary SCLC is rarely occult because it is aggressive and fast-growing. In our case, chest and abdominal CT revealed no other lesions, and the thyroid mass was determined to be the primary lesion. 
There is not a consensus about the best treatment approach in EPSCC, including the thyroid primaries, since these tumours are rare and there isn't specific data about it. As the clinical course of these tumours resemble lung small cell neuroendocrine primaries, the treatment often used is similar. ${ }^{25}$ In the scenario of a localized disease, the most used approaches are local treatment with surgery and/or radiotherapy, and chemotherapy. In our case, after thyroidectomy the patient was submitted to locoregional radiotherapy including the lymphatic drainage and conventional chemotherapy used for lung small cell carcinoma, with four cycles of cisplatin and etoposide. ${ }^{25}$
A systemic treatment for this disease seems to be important, since it has an aggressive approach with early systemic dissemination. ${ }^{26}$ We also used in our patient a second line protocol that is active in small cell lung cancer, consisting of vincristine, adriblastine and cyclophosphamide. There are also controversies regarding prophylactic cranial irradiation $(\mathrm{PCI})$ in this scenario. Extrapulmonary small cell neuroendocrine carcinomas seems to develop less frequently cerebral metastasis than their lung primary counterpart, with an overall incidence of $6 \% .{ }^{27}$ Despite this, it seems that the head and neck small cell neuroendocrine carcinoma has a higher incidence $(41 \%)$ of central nervous system disease, ${ }^{27}$ and $\mathrm{PCl}$ can be considered.

\section{AUTHOR'S CONTRIBUTION}

Maria Clara Martins Prado: Collection and assembly of data, Conception and design, Data analysis and interpretation, Final approval of manuscript, Manuscript writing, Provision of study materials or patient.

Isabella Rocha França Longo Staino: Collection and assembly of data, Conception and design, Data analysis and interpretation, Final approval of manuscript, Manuscript writing, Provision of study materials or patient.

Hannah Damasceno Barreto da Silva: Collection and assembly of data, Conception and design, Data analysis and interpretation, Final approval of manuscript, Manuscript writing, Provision of study materials or patient.
Alexandre Fonseca de Castro: Collection and assembly of data, Conception and design, Data analysis and interpretation, Final approval of manuscript, Manuscript writing, Provision of study materials or patient.

Lysio França: Collection and assembly of data, Conception and design, Data analysis and interpretation, Final approval of manuscript, Manuscript writing, Provision of study materials or patient.

Paula Ferreira Barros: Collection and assembly of data, Conception and design, Data analysis and interpretation, Final approval of manuscript, Manuscript writing, Provision of study materials or patient.

\section{REFERENCES}

1. Vrouvas J, Ash DV. Extrapulmonary small cell cancer. Clin Oncol (R Coll Radiol). 1995;7:377-8.

2. The NCCN Clinical Practice Guidelines in Oncology ${ }^{\mathrm{TM}}$. Neuroendocrine tumors. @National Comprehensive Cancer Network - NCCN, Inc; 2018. Available from: http://www.nccn.org

3. Oesterling JE, Hauzeur CG, Farrow GM. Small cell anaplastic carcinoma of the prostate: a clinical, pathological and immuno-histological study of 27 patients. J Urol. 1992 mar;147(3 Pt 2):804-7.

4. Kanat O, Evrensel T, Adim SB, et al. Small cell carcinoma of the urinary bladder. A clinicopathologic study of five cases. Tumori. 2003 may-jun;89(3):328-30.
5. Brenner B, Shah MA, Gonen M, et al. Smallcell carcinoma of the gastrointestinal tract: a retrospective study of 64 cases. $\mathrm{Br}$ J Cancer. 2004 may;90(9):1720-6.

6. Majhail NS, Elson P, Bukowski RM. Therapy and outcome of small cell carcinoma of the kidney: report of two cases and a systematic review of the literature. Cancer. 2003 mar;97(6):1436-41.

7. Samli B, Celik S, Evrensel T, et al. Primary neuroendocrine small cell carcinoma of the breast. Arch Pathol Lab Med. 2000 feb;124(2):296-8.

8. Eichhorn JH, Young RH. Neuroendocrine tumors of the genital tract. Am J Clin Pathol. 2001 jun;115(Suppl):S94-112. 
9. Ferlito A. Diagnosis and treatment of small cell carcinoma of the larynx: a critical review. Ann Otol Rhinol Laryngol. 1986 nov;95(6):590-600.

10. Renner G. Small cell carcinoma of the head and neck: a review. Semin Oncol. 2007 feb;34(1):3-145.

11. Kumar LP, Armugham N, Triveni B, Krishna MR. Neuroendocrine tumor of larynx: A review of literature. Asian J Oncol. 2015 jan;1:33-6.

12. Eusebi V, Damiani S, Riva C, Lloyd RV, Capella C. Calcitonin free oat-cell carcinoma of the thyroid gland. Virchows Archiv A Pathological Anatomy and Histopathology. 1990;417:267-271.

13. ChornyJA, Orego JJ, Cameselle-TeijeiroJM. Primary high-grade calcitonin-negative neuroendocrine carcinoma of th thyroid: a very

rare cancer. Endocrinol Diabetes Metab Case Rep. 2018 apr;2018.pii:18-0036.

14. Beach DF, Klump WJ, Haddad G, Reid LM, Schwarting R, Hageboutros A. Extrapulmonary small cell: a novel case of small cell carcinoma of the thyroid gland. Medical Oncology 2012;29:1405-1408.

15. Mussazhanova Z, Miura S, Stanojevic B, Rougounovitch T, Saenko V, Shiraishi T, Kurashige T, Shichijo K, Kaneko K, Takahashi

16. $\mathrm{H}$, et al. Radiation-associated small cell neuroendocrine carcinoma of the thyroid: a case report with molecular analyses. Thyroid. 2014 mar;24(3):593-8.

16. Ortansa MR, Rodica A, Dumitrache M, Adriana C, Oprea V, Mitulescu D. Small cell neuroendocrine thyroid carcinoma. Therapeutics, Pharmacology and Clinical Toxicology 2014;18:171-173.

17. Cruz J, Eloy C, Maria Aragüés J, Vinagre J, SobrinhoSimões M. Small-Cell (Basaloid) Thyroid Carcinoma: A Neoplasm With a Solid Cell Nest Histogenesis?. International Journal of Surgical Pathology. 2011 apr;19(5):620-626.
18. Eloy C, Manuel Cameselle-Teijeiro J, Rousseau E, Sobrinho-Simões M. Small Cell Tumors of the Thyroid Gland: A Review. International Journal of Surgical Pathology. 2013 nov;22(3):197-201. Braz J Oncol. 2019; Primary small cell carcinoma of the thyroid: a case report 5

19. Brenner B, Tang LH, Klimstra DS, et al. Small-cell carcinomas of gastrointestinal tract: a review. J Clin Oncol. 2004 jul;22(13):2730-9.

20. Frazier SR, Kaplan PA, Loy TS. The pathology of extrapulmonary small cell carcinoma. Semin Oncol. 2007 feb;34(1):30-8.

21. Welborn J, Jenks $H$, Taplett $H$, et al. Highgrade neuroendocrine carcinomas display unique cytogenetic aberrations. Cancer Genet Cytogenet. 2004 nov;155(1):33-41.

22. Kurt E, Sezgin C, Evrensel T, Yalcinkaya U, KanatO, Veral A, Demiray M, Arslan M, Karabulut B, Ercan I, Goker E, Manavoglu O. Therapy, outcome and analysis of c-kit expression in patients with extrapulmonary small cell carcinoma. Int J Clin Pract. 2005 apr;59(5):537-543.

23. Sehgal IS, Kaur H, Dhooria S, et al. Extrapulmonary small cell carcinoma of lymph node: Pooled analysis of all reported cases. World J Clin Oncol. 2016 jun;7(3):308-20.

24. Kim JH, Lee S-H, Park J, et al. Extrapulmonary small cell carcinoma: a single institution experience. Jpn J Clin Oncol. 2004 may;34(5):250-4.

25. Yasumatsu R., Nakashima T, Yamauchi M, Toh S, Komune S. Extrapulmonary small cell carcinoma in head and neck. The Journal of Laryngology \& Otology. 2015 mar;129(S2):S83-S85.

26. Soto DE, Eisbruch A. Limited-stage extrapulmonary small cell carcinoma: outcomes after modern chemotherapy and radiotherapy. Cancer J. 2007 jul/ago;13(4):243-6.

27. Yazıcı O, Ozdemir NY, Sendur MA, et al. Current approaches for prophylactic cranial irradiation in extrapulmonary small cell carcinoma. Curr Med Res Opin. 2014 jul;30(7):1327-36. 